\title{
Designing and Building Client-Server Based Student Admission Applications
}

\author{
Arip Solehudin ${ }^{1}$ \\ Teknik Informatika \\ School of Computer science \\ Universitas Singaperbangsa Karawang \\ arip.solehudin@gmail.com
}

\author{
Nono Heryana ${ }^{2}$ \\ Teknik Informatika \\ School of Computer science \\ Universitas Singaperbangsa Karawang \\ nonoheryana@staff.unsika.ac.id
}

\author{
Yana Cahyana ${ }^{3}$ \\ Teknik Informatika \\ School of Engineering and Computer Science \\ Universitas Buana Perjuangan Karawang \\ yana.cahyana@ubpkarawang.ac.id
}

\begin{abstract}
$<\beta$ organized by the Educational Institution. Early Childhood Education (PAUD) is included in out-of-school education in the age range of two to five years, the goal is to help improve physical and spiritual growth and development so that children have the readiness to enter further education. Admission of New Students to Al-Qudwah is still done using prospective students visiting Al-Qudwah and filling out the registration form with paper. New Student Admission Application at Al Quwah aims to promote the school to the community at large and can also be registered without parents of prospective students visiting educational institutions. This application makes it easy for parents of prospective students to find out the facilities and infrastructure and the information available on Al Quwah. We built this application using HTML and PHPprogramming languages with the PHP MySQL database and using the waterfall method.
\end{abstract}

\section{THEORETICAL BASIS}

Keywords-Application, Admission, Website,UML, Waterfall

\section{INTRODUCTION}

PAUD-level education is currently in demand by parents in helping the growth and development of children with the hope that children are better prepared to enter the next level of education. Before entering, of course, parents will consider and look for information about which PAUD they will choose to assume responsibility for educating their children. Usually, the information that parents look for about the condition of their school, the curriculum taught, admission fees, monthly administration, and what learning activities are available at these PAUD institutions.

The development of information technology currently plays an important role in the development of information, especially internet users because the results of the information technology make communication limited by time and space to make communication without space and time restrictions. With the presence of the internet to provide alternatives for users in utilizing the information search needed. Through the internet, it can provide the speed of information every time requires information, detail and free of cost. So that in Indonesia there are many internet users every year.

In general, the purpose of using the internet is to obtain and share information. The development of the internet has penetrated the field of education to make competitive competition between educational institutions.

\section{A. Understanding New students}

Acceptance is a welcome process, act or attitude towards someone. Students are students at an academy or college. New is something that did not exist before. New Student Registration (PSB) is the activity of accepting and selecting prospective participants in education and training at schools. Admission of New Students (PSB) is a process of academic selection of prospective students towards higher education [3].

\section{B. Website}

The website is one application that contains multimedia documents (text, images, sound, animation, video) in it that uses the HTTP protocol (hypertext transfer protocol) and to access it using a software called a browser. Some types of popular browsers today include Internet Explorer produced by Microsoft, Mozilla Firefox, Opera, and Safari produced by Apple [2].

\section{UML}

Unified Modeling Language (UML) is a standard specification language used to document, specify and build software. UML is a methodology in developing objectoriented systems and is also a tool to support system development [4].

\section{Waterfall}

The method used by the author in developing this software uses the waterfall model. The Waterfall model is often also called the Sequential Linear or Classic Life Cycle model. The waterfall model provides a sequential or sequential software life cycle approach starting from analysis, design, coding, testing and support stages [5].

\section{E. System}

Is working mobility of procedures or elements that are interconnected, gathered together to carry out an activity or to solve a problem [1].

\section{RESEARCH METHODS}

The method of developing applications for new student admissions was created using the waterfall method. 


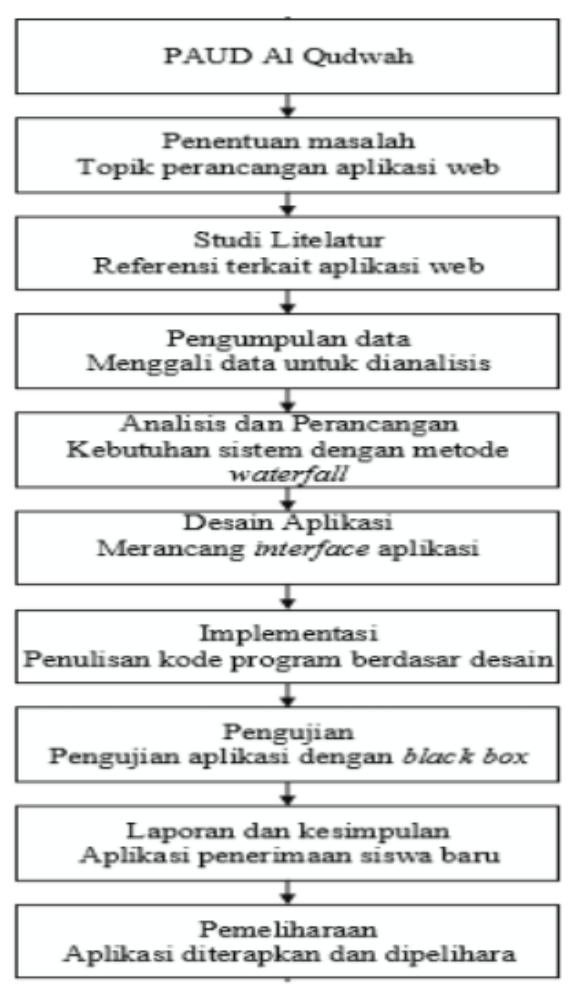

Fig. 1. Waterfall Method

\section{RESULT AND DISCUSSION}

A. Proposed Application Design

1. Use Case Diagrams

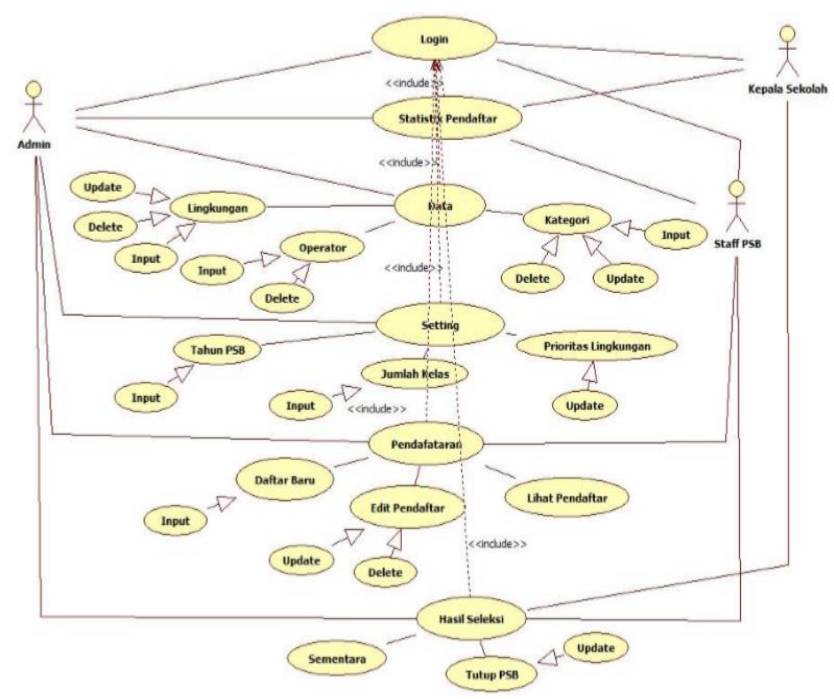

Fig. 2. Use Case Operator Diagram

2. Activity Diagram

Activity diagram illustrates the workflow or work activities of the application to be implemented. The following is an activity diagram of the proposed application that will be implemented.

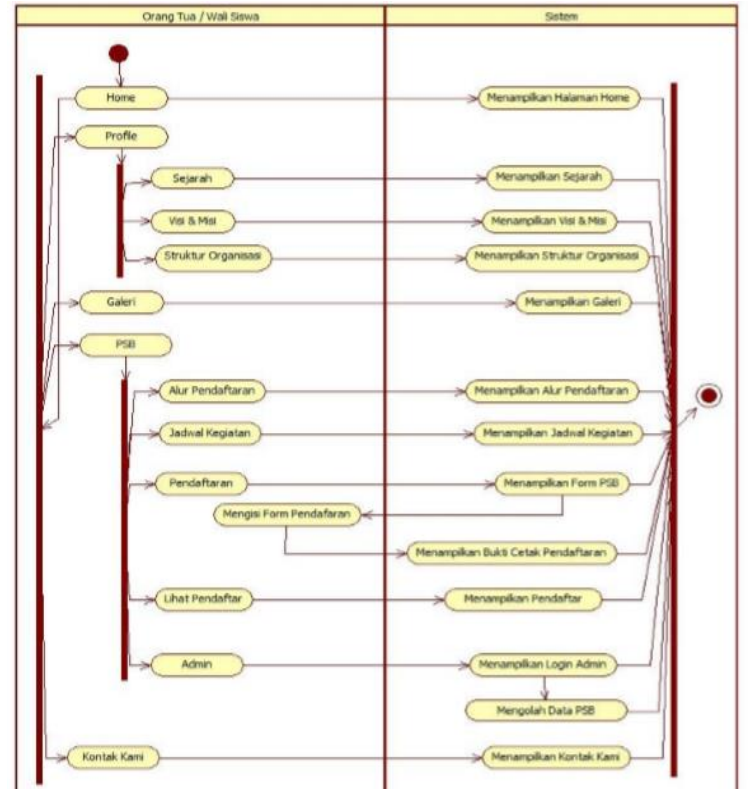

Fig. 3. Activity Diagram

3. Class Diagram

Class diagrams are used to describe the relationship between the classes of a system. Following is the class diagram of the New Student Admissions application.

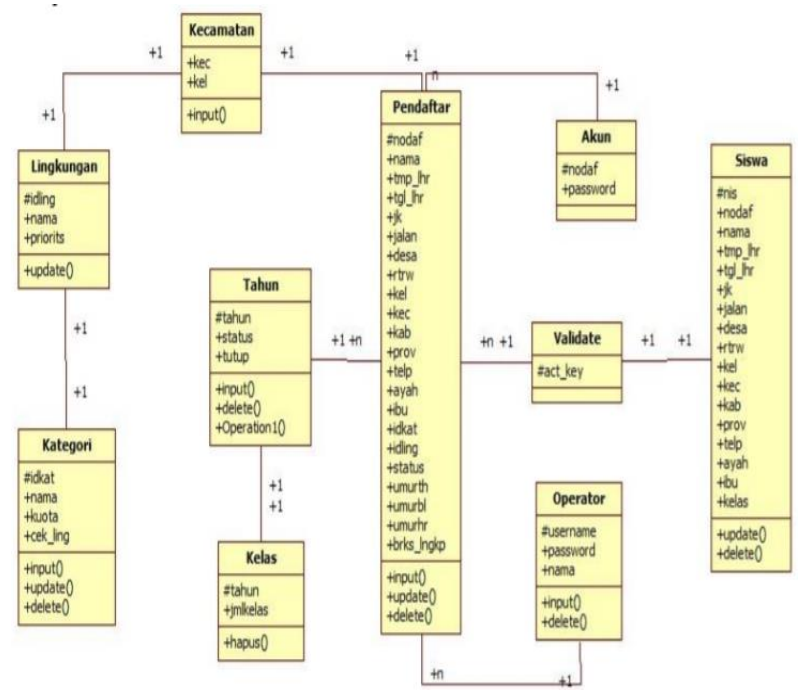

Fig. 4. Class Diagram

B. Implementation

1. Main page display 


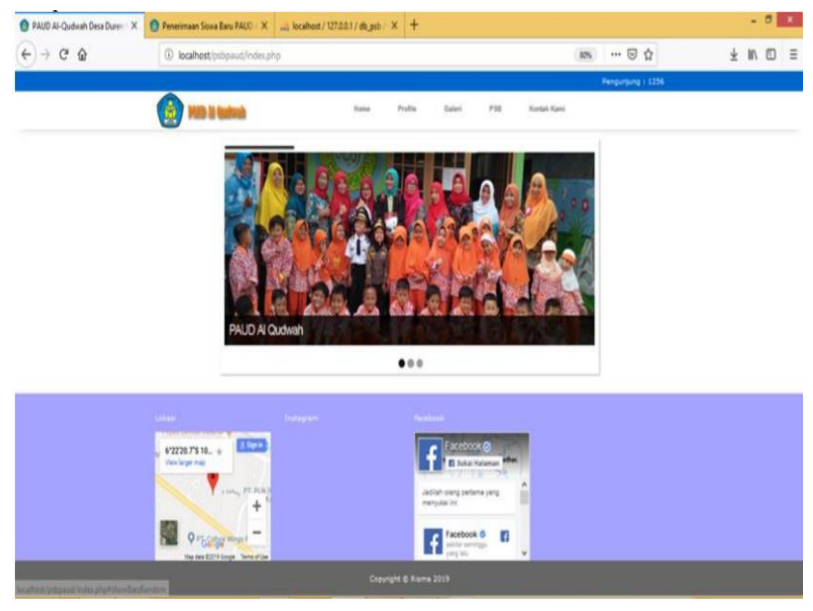

Fig. 5. Main Page Display

1. PSB Display

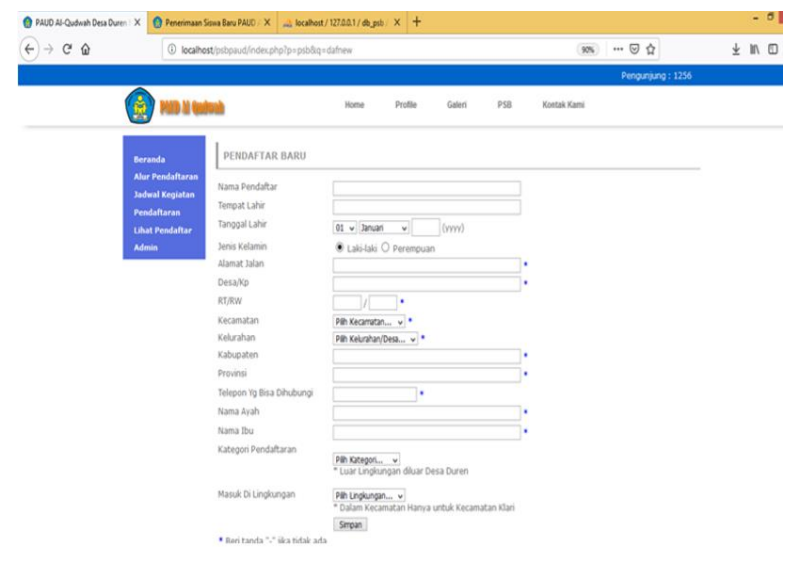

Fig. 6. PSB Display

\section{CONCLUSION}

The conclusions the author can draw that are: The acceptance system in Al Qudwah PAUD after observation is still manual so it is feared the loss of registration data because of damage or fire, with the website application developed by the author can minimize losses data because registration data is stored on a database.

New Student Admission Applications can media for publication and also to develop information technology, so that information got is fast and efficient.

Storage of registration records is still done in physical form, in this application each participant has a personal account to view the track record and results got.

\section{REFERENCES}

[1] Bayu Priyatna, penerapan metode user centered design (ucd) pada sistem pemesanan menu kuliner nusantara berbasis mobile android, Account. Inf. Syst. PENERAPAN, pp. 17-30, 2018.

[2] Arief, M. Rudyanto., 2011. Pemrograman Web Dinamis Menggunakan PHP dan MySQL: Andi Publisher.

[3] Hendini, Ade., 2016. Pemodelan Uml Sistem Informasi Monitoring Penjualan Dan Stok Barang (Studi Kasus: Distro Zhezha Pontianak). Jurnal Khatulistiwa Informatika, Vol. Iv, No. 2 Desember 2016, Hlm. 107-116.

[4] Witanto, Regi., Solihin, Hanhan Hanafiah.,2016. Perancangan Sistem Informasi Penerimaan Siswa Baru Berbasis Web (Studi Kasus : Smp Plus Babussalam Bandung). Jurnal Infotronik Volume 1, No. 1, Desember 2016, hlm. 54-63.

[5] Pranata, Dana., \& Hamdani., \& K, Marisa, Dyna. 2015. Rancang bangun website jurnal ilmiah bidang komputer. Jurnal Informatika Mulawarman. Vol.10. 